\title{
Responding to Public: \\ Policy Responsiveness by Political Parties in the European \\ Parliament*
}

\section{$\mathrm{H}$ an, JeongH un}

(Seoul National University)

\section{$\langle$ CONTENTS〉}

I . Introduction

II. MEPs' Distinct Voting Patterns

III. Voters' Revealed Preferences in EP elections

IV. A Theoretical Model of Legislative Voting Behavior in Two-level Party System
V. An Empirical Model of National Party Responsiveness

1. Measuring National Party Cohesion

2. Data, Variable, Model and Hypotheses

3. Empirical Results

VI. Conclusions

- Keyword: EP, Legislators' Responsiveness, Two-level party system, EP elections, Party Cohesion

\section{【ABSTRACT】}

Traditional theories of party representation require parties in legislatures to repond to voters by converting voter preferences into public policy. This article studies to what extent this requirement is achieved by parties in the European Parliament(EP). Recognizing distinct features of the two-level party system inside the EP, this artilce suggest a micro foundation linking voters' party support in EP elections into strategic voting behavior of members of the EP(MEPs) with a focus on the role of national parties. After developing a new measure of national party party cohesion, I empirically test the electoral impact on the national party cohesion with data covering five consequent EP elections from 1979. Results show a high level of electoral volatility among a party supporters, by lowering MEPs' expection of re-election, are more likely to lead MEPs of the party vote together inside the EP despite the influence of their European party.

* This research is a revised version of one chapter in my Ph.D thesis. The eariler version was presented at the 2007 annual conference of the Korean Political Science Association in Pusan. I would like to thank G. Bingham Powell, Bonnie M. Meguid, Simon Hix, discussants of the KPSA conference and three anonymous reviewers for their helpful comments. All errors are mine. 


\section{I . Introduction}

One important requirement of theories of party representation is that parties in legislatures should respond to their voters by converting voters' policy preferences into public policies(Ranny 1962; Sartori 1968; Katz 1987; Dalton and Wattenberg 2001). ${ }^{1)}$ In legislatures with normal party system, parties carry out this role by working cohesively in the processes of decision making and thus by implementing the policies that they proposed to voters in elections.

However, this connection between voter preferences and public policies through the role of parties in legislatures is more difficult to accomplish in multi-level party systems. In particular, in the distinct two-level party system ${ }^{2)}$ of the European Parliament(EP) in which national and European parties have different representational foci, national parties often fail to support their proposed policies in EP elections whenever the influence of the European Party Groups(EPGs) on their individual members of the EP(MEPs) overwhelms in those conflicting issues between the two-level parties. In addition, since the EPGs have little role in selecting candidates and providing policy alternatives in EP elections, European policies on which the EPGs are much more influential would raise a serious question about paraties' responsiveness to their electorate.

It is thus problematic that previous research on the EP has rarely considered whether the decisions made inside the EP are conformable to voter preferences. At best, scholars of the EP has provided an indirect evidence of the responsiveness by showing the extent of existing policy congruence at the perceptual level between European mass public and political elites in the EP(Schmitt and Thomassen 1999, 2000). To the extent that the EPGs provide MEPs with incentives to defect from the policy proposals promised by their national parties in EP elections, the policy implementation inside the EP would be entirely ruled in consistence with this perceptual policy congruence. In this light, Hix's (2004) recent exploration into the dependency of MEPs' voting behavior on the

1) Ranny(1962) sets out three minimum conditions on which parties in government are understood to have a democratic mandate to implement their agenda for the duration of their term of office. The question of legislators' responsiveness to voter preferences is one of them. For more details of the conditions, see Ranny(1962).

2) The two-level party system in the EU denotes the party system consisting of national parties at the national level and European Party Groups(EPGs) at the European level. While national parties are said to put more emphasis on the responsiveness to their electorate in their respective member state, the EPGs as coalitions of various national parties with similar ideological orientation tend to focus on the responsiveness to pan-European people. 
respective electoral institutions of member states makes a big progress in studies of legislators' responsiveness inside the EP. Although we can draw valuable insights on the relative frequency of MEPs' support between their national and European party, we are still in doubt of why some MEPs or national parties as the aggregation of them in almost similar institutional set-ups make different legislative decisions.

This paper redresses this research gap. In particular, focusing on the connection between voters' preferences revealed by their support for parties in EP elections and national parties' responsiveness through their members' voting behavior, this paper would make legislators' responsiveness build on firm, largely indisputable evidence about the choices made by citizens(Powell 2000, 16). Moreover, it would go beyond Hix's (2004) institution deterministic approach to MEPs' voting behavior. Seeking a micro foundation in which MEPs strategically decide to support either of the conflicting positions taken by their national party and the EPG from their reelection calculation, this paper argues that the responsiveness among national parties depends not only on institutional factors but also on voters' change of party support in EP elections. In this way, this paper establishes a more direct connection between voters' revealed preferences and the enacted European policies.

Empirical analysis in this paper, with data covering MEPs' roll call votes from the First and the Fifth EP and the relevant election data, confirms the main hypothesis such that the level of national party responsiveness is determined by the magnitude of voter change of party support between each EP election and the previous national elections. In addition, it finds that this responsiveness is conditioned on the strength of national party measured by the candidate selection processes varying between national parties.

The results here thus show that MEPs who develop a low reelection expectation from voters' volatile support between the two elections are more likely to be disciplined by their national parties and thus more likely to respond to their party supporters. One implication would be that for further development of European integration, increasing role of the EPGs on MEPs' voting behavior inside the EP should proceed with the agreement with their member national parties. In addition, this research would be an empirical evidence for the generalization of the role of parties in the development of political representation.

Although new, this research on party responsiveness in the European two-level party system should confront with inescapable challenges. In particular, the questions of what preferences voters provide MEPs with their change of support between the two elections and how we can measure national party cohesion in the distinct two-level party system 
inside the EP should be resolved. Therefore, in the next section I begin with resolving the first question after considering the institutional features under which MEPs make their voting decisions. Next, I present a micro foundation from which a new measure of national party responsiveness could be derived. After developing the measure, I empirically test the impact of voters' electoral choices on the national party cohesion. Finally, conclusions will follow.

\section{II . MEPs' Distinct Voting Patterns}

Unlike other legislatures, MEPs' voting behavior in the two-level party system inside the EP shows very interesting features. In general, three components underlying individual legislators' voting behavior are said to be voter preferences, party affiliation and legislators' individual preference(Levitt 1996). But, with respect to MEPs' voting behavior, we need to pay attention to the fact that there are two different kinds of party affiliation, which often makes MEPs' voting decisions more complicated. Specifically, if a voting issue is agreed between a national party and its EPG, then an MEP of a member of both the national party and the EPG would be in a similar situation to legislators of other normal legislatures. The MEP, by choosing an alternative, decides either to follow the issue position of her party or to defect from it. Meanwhile, if a national party and its EPG have conflicting positions on some issues, an MEP of a

〈Figure 1〉 Types of MEPs' Vote Decisions*

\begin{tabular}{|c|c|c|c|c|}
\hline \multirow{3}{*}{ 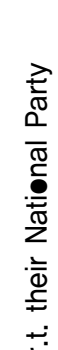 } & & \multicolumn{3}{|c|}{ MEPs' Decision w.r.t. their Eurøpean Party Grøup } \\
\hline & & $\begin{array}{c}\text { Vote with Party } \\
\text { Majority }\end{array}$ & $\begin{array}{l}\text { Defect from Party } \\
\text { Majority }\end{array}$ & Total \\
\hline & $\begin{array}{c}\text { Vote with } \\
\text { Party } \\
\text { Majority }\end{array}$ & $\begin{array}{c}\mathrm{A} \\
(88.8 \%)\end{array}$ & $\begin{array}{c}\mathrm{B} \\
(7.8 \%)\end{array}$ & $\begin{array}{c}A B=A+B \\
(96.6 \%)\end{array}$ \\
\hline $\begin{array}{l}\frac{1}{3} \\
\frac{c}{0} \\
\frac{0}{0} \\
0\end{array}$ & $\begin{array}{c}\text { Defect from } \\
\text { Party } \\
\text { Majority }\end{array}$ & $\begin{array}{c}\mathrm{C} \\
(1.0 \%)\end{array}$ & $\begin{array}{c}\mathrm{D} \\
(2.4 \%)\end{array}$ & $\begin{array}{c}C D=C+D \\
(3.4 \%)\end{array}$ \\
\hline 嵒 & Total & $\begin{array}{c}A C=A+C \\
(89.8 \%)\end{array}$ & $\begin{array}{c}\mathrm{BD}=\mathrm{B}+\mathrm{D} \\
(10.2 \%)\end{array}$ & $\begin{array}{l}\text { ABCD } \\
(100 \%)\end{array}$ \\
\hline
\end{tabular}


member of both parties should choose either of the positions of her two parties. By supporting for her national party, she defects from her EPG. By defecting from her national party, she supports her EPG.

Figure 1 illustrates these features of MEPs' voting decision. Among 636 roll calls of the first half of the Fifth EP, 90\% of them, A+D, were roll calls that national parties and their respective EPGs agreed each other. MEPs, by defecting from their national party in these roll calls, also defect from their EPG. Meanwhile, for the remaining 10\% of total roll calls, MEPs have to defect either of their two parties when they support one of the issue positions of their two parties.

Previous research has studied MEPs' voting behavior without fully specifying these patterns. For example, previous studies showing increasing cohesion among the EPGs inside the EP take into account only the division between AC and BD(Attina 1990; Raunio 1996; Kreppel 2000, 2002; Gabel and Hix 2002; Hix et al. 2007). In other words, they did not distinguish MEPs' defection from the majority of both their two parties (D) from their defection only from the majority of their EPG (B) and treated them as those having same meaning of MEPs' defection from their EPG's positions. As a consequence, when they aggregate MEPs' voting decisions with respect to party membership, they lose lots of information about the relative magnitude of MEPs' support for either of their two parties in the issues of conflicting between the two parties.

Improving upon the previous poor specification of MEPs' voting behavior, this article claims that $\mathrm{B}$ and $\mathrm{C}$ types of voting behavior would contains more important information to show varying degrees of party responsiveness among national parties in two respects. First, since the A type of MEPs' voting decision occur when there are agreements between their national party and their respective EPG, we can not differentiate the relative influence imposed by the two parties on MEPs' voting decisions. Second, it would not be unreasonable to assume that the A type of MEPs' voting decision, which represents policy implementation through MEPs' supporting for the agreed positions between national parties and the EPGs, would not deviate too much from the policies proposed by national parties in EP elections. Thus, while MEPs implement close policies proposed in EP election by the A type of voting behavior, their responsiveness would differ depending on the frequency of the $\mathrm{B}$ and $\mathrm{C}$ types of voting behavior. Then, the next question would be; why do MEPs show the varying frequencies in their voting behavior between $\mathrm{B}$ and $\mathrm{C}$ types? 


\section{Voters' Revealed Preferences in EP elections}

The standard approach to EP elections has treated EP elections as dependent on the national elections in each member state(Reif and Schmitt 1980; Reif 1984, 1985; Oppenhuis et al. 1996; van der Eijk et al. 1996; Kousser T.B. 2003). As Reif and Schmitt (1980:8) point out EP elections are second-order national competitions by which no institutionally binding consequences on government or opposition policies at the national level are decided. In addition, since the Council of the Ministers is a co-equal legislator with the EP in European decision making(Crombez 1997; Han 2007b), European voters would use national elections to choose those who represent them in the Council of the Ministers. In these regards, voters' party support in EP elections cannot be viewed without considering national politics in each member state. For example, voters may cast sincere votes in EP elections without fear of wasting their votes on national parties with no chance of forming a government(Reif 1984, 1985), signal their protest against the policies implemented by governing parties without at all affecting the distribution of political power at the national level(van der Eijk et al. 1996; Oppenhuis et al. 1996), or even punish their governing parties, depending on their retrospective evaluation of the government's economic record(Kousser; 2004).

However, out impression of EP elections may not support the entire dependency of EP elections on national politics. Voters in fact vote for some Europe-specific issue parties in EP elections. Parties dealing with issues beyond borders, i.e. Green parties, are more likely to gain their support in EP elections. Ferrarra and Weishaupt(2004) also show that national parties' positions on the issues of European integration significantly affect voters' party support in EP elections. All these are examples showing that although voters' party support in EP elections may in large part depend upon national politics, European voters do not completely ignore European politics themselves when they choose their representatives in EP elections. In contrast, by changing their party support between each EP election and the previous national election, voters in each member state would in some part try to send their European representatives what they want at the European level politics.

From this consideration, most plausible assumption would be that voters reveal different assessment on their national parties' performance at the European level by their changes of party support between each EP election and the previous national election. Similar to Butler and Stokes's(1976) argument, electoral volatility between the two elections would function as a precursor of de-alignment or future re-alignment of existing partisan voting in EP elections. Then, in response to the potential of voters' 
future re-alignment, MEPs would in turn develop their re-election expectation. For example, if there is a high volatile party support, MEP of the national party would expect that a large portion of their party supporters would not make clear partisan voting in EP elections. As a consequence, the unstable party support in EP elections would lead MEPs to focus on the competition for acquiring a higher post in the candidate list of their national party and thus to be more likely to be controlled by their national party leadership.

〈Table 1〉 Relationships between Electoral Volatility and MEPs' Defection*

\begin{tabular}{c|c|c}
\hline Electoral Volatility & $\begin{array}{c}\text { Average Rate of } \\
\text { Defection from NP Majority }\end{array}$ & $\begin{array}{c}\text { Average Rate of } \\
\text { Defection from EPG Majority }\end{array}$ \\
\hline High Electoral Volatility & $0.83(\%)$ & $6.90(\%)$ \\
\hline Low Electoral Volatility & $1.52(\%)$ & $6.65(\%)$ \\
\hline $\begin{array}{c}\text { Correlation Coefficient } \\
\text { with each type of defection }\end{array}$ & -0.16 & 0.26 \\
\hline
\end{tabular}

* The figures in the cell are the average percentage of the defection rates of 28 major national parties of 14 member states, consisting of two major national parties in each member state which represent Left/Right positions. MEPs of the Luxembourg are not considered because of its small number. National parties considered in this table are as follows. Austria: SPO, OVP; Belgium: VLD, PS; Denmark: V, SD; Finland: KOK, SDP; France: PS, UDF; Germany: CDU, SPD; Greece: ND, PASOK, Ireland: FF, FG; Italy: DS, FI; Netherlands: CDA, PvdA, Portugal: PSD, PS; Spain: PP, PSOE; Sweden: M, SAP; UK: LAB, CON. Date source: roll call data used for the Figure 1 for the average rate of defection; election results in each member state from kissing's Archive and Europa Year Book for the average rate of electoral volatility.

This negative relationship between electoral volatility and the frequency of MEPs' support for their national party positions in the issue of conflicting between their national party and their EPG can be validated by using data of MEPs' voting records and election results. Table 1 presents the overall pattern of the relationship. For MEPs of 28 major left/right national parties in each member state except the Luxembourg in the Fifth EP, they, other things being equal, are more likely to defect from their national party majority and less likely to defect from their EPG majority when the electoral volatility in their party supporters is high, or vice versa. For instance, MEPs of national parties with high levels of electoral volatility are less likely to defect from their national party positions $(0.83 \%)$ and thus they are more likely to support for their EPG in the issues of conflicting between two parties. With this observed relationship, I in the next section suggest a theoretical model of MEPs' voting decisions. 


\section{A Theoretical Model of Legislative Voting Behavior in Two-level Party System}

In this section, I develop a hypothetical mechanism of MEPs' voting behavior based on their strategic response to party supporters in EP elections. Considering the interactions between MEPs' strategic responsiveness and the institutionally determined power of their national party, this model improves previous Hix's(2004) work and provides a micro foundation of national party's responsiveness in the processes of European decision making.

Figure 2 illustrates the mechanism linking an individual MEP's voting decisions and her party supporters in EP elections. In this model, MEPs are assumed to be re-election seeking representatives. Their voting decisions depend on two factors; how stable their voters' support is in EP elections and how institutionally strong their national party is. After considering these two factors, each MEP decides their vote in European decisions. In particular, since we have much more interests in how MEPs behave in issues of conflicting between their two parties, I limit my attention on the frequency of voting in the cells, B and $\mathrm{C}$, which represents the cases in which MEPs support either of the positions taken by their two parties in issues of conflicting between them.

〈Figure 2〉 An MEP’s Strategic Voting Responsiveness

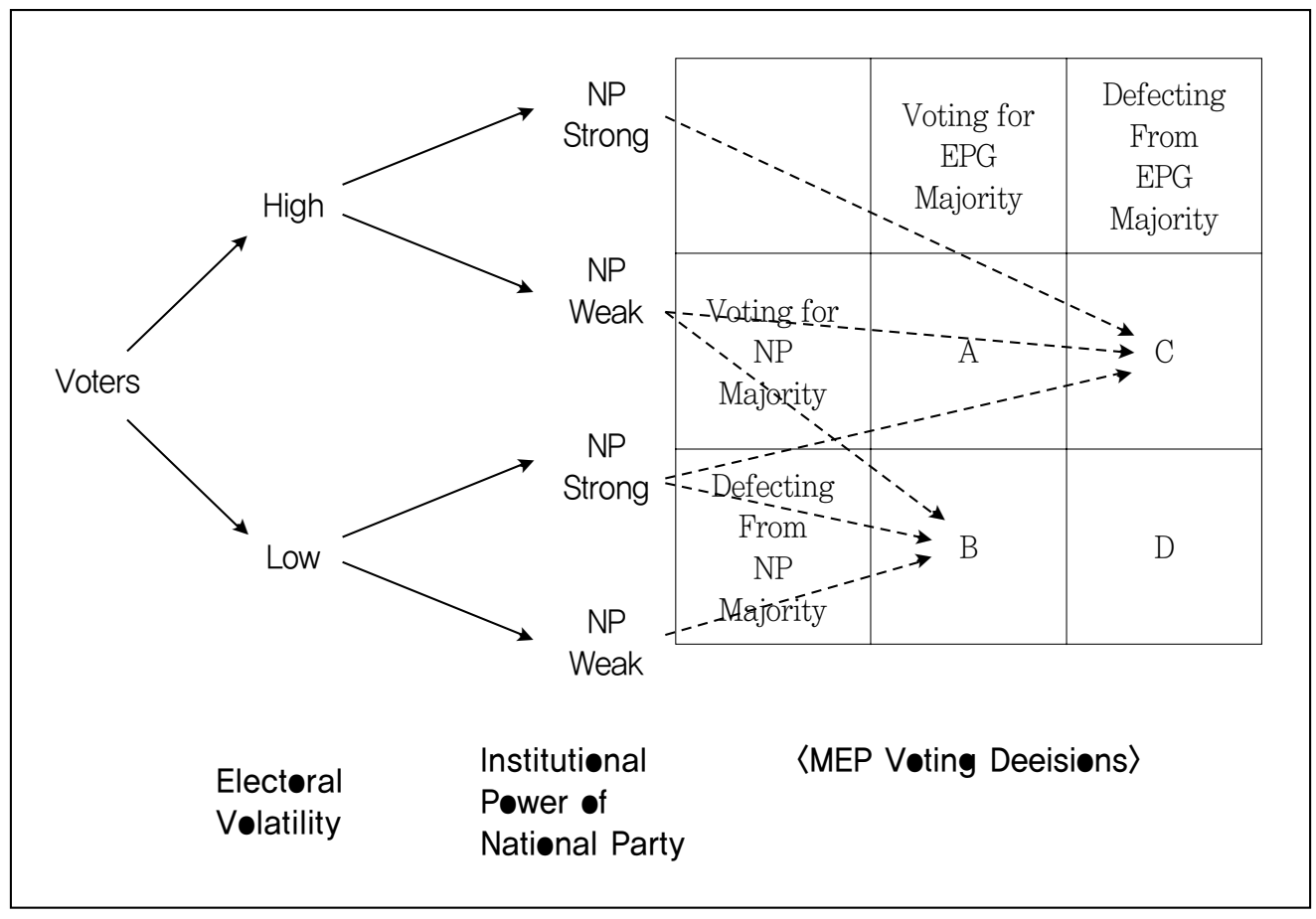


Hix(2004) argues that only institutional power of national party determines MEPs' support for either of positions taken by their two parties in issues of conflicting between them. As he does not consider the effect of electoral volatility, variations in MEPs' voting decisions are highly restricted. For example, according to his analysis, only two hypotheses would be plausible. MEPs of a strong national party would be more likely to support for their national party rather than their EPG(an arrow from an MEP of a strong national party to C). MEPs of a weak national party would be more likely to support for their EPG rather than their national party(an arrow from an MEP of a weak national party to B). By considering MEPs' responsiveness to their party supporters, this somewhat deterministic relationship could be extended further.

In Figure 2, although the party strength has an effect on the MEP' $\mathrm{s}$ decisions, it is in fact conditioned on her responsiveness to her party supporters in EP elections. First, if voters reveal a high volatility when they support a national party between each EP election and the previous national election, the institutional strength of a strong national party on their members would be reinforced(an arrow from an MEP of a strong national party with a high electoral volatility to $\mathrm{C}$ ). The reason of this reinforcement is derived from their member MEPs' incentives to put more emphasis on their party organization due to the low reelection expectation developed from the unstable support in EP elections. In addition, the high volatility also increases the organizational power of a weak national party. By voting together with her colleagues, an MEP would take advantage of other members' popularity in public and thus find a safer shelter of her re-election under her national party flag in EP elections.

Second, if voters reveal a low volatility in their national party support between the two elections, the stable support allows MEPs to behave as pan-European representatives without restricted to local or regional interests. An MEP of a weak national party would not significantly change their voting decision with voters' stable support(an arrow from an MEP of a weak national party with a low electoral volatility to B). Meanwhile, an MEP of a strong national party would increase the chances of defecting from their national party position(an arrow from an MEP of a strong national party with a low electoral volatility to C). This MEP's defection from her strong national party is possible since the only thing that she cares about would secure her previous post within her national party list. It is expected that she would survive even with some defection from her national party majority in so far as her national party leaders are tolerant of her defection.

This hypothetical model of an MEP's voting behavior, focusing on issues of conflicting between her two parties, provides a micro foundation of how MEPs strategically respond 
to their voters' electoral choices. In addition, the model makes it an empirically testable question whether or not MEPs' voting behavior in fact depend on the electoral volatility revealed by their party supporters after controlling for some factors derived from national politics and the institutional power of national parties. To do this analysis at the national party level, I first develop a new way of aggregating each MEP' s support for her national party rather than her EPG, which measures national party cohesion in the two-level party system inside the EP. With this new measure of national party

cohesion, I next empirically test the impact of voters' electoral choices on national party cohesion, or equivalently national party responsiveness here.

\section{An Empirical Model of National Party Responsiveness}

\section{Measuring National Party Cohesion}

Traditionally, party cohesion in legislative voting behavior refers to the extent to which the party members vote together. The more frequently party members defect from their party's positions because of their individual preferences, the less party cohesion will result in. The two-level party system inside the EP makes this measuring party cohesion more complicated. That is, when there are conflicts between a national party and its EPG, their member MEPs may improve the party cohesion in one level by simultaneously hurting it in the other level. For example, when the British Labor party and the European Socialist Group (SOC) take different positions in European economic issues when the British prime minister, Tony Blair, announced a liberal economic positions in the Fourth EP, a British Labor MEP, Ken Coates, lowered her national party cohesion by defecting from the Labor's positions on lots of relevant roll calls. But, his support for the SOC in those roll calls contributed to improving the SOC's cohesion.

Given this institutional feature, this article develops a new measure of national party cohesion after considering the influence of EPGs on the members of each national party. To disentangle this relative influence of two parties on their members' voting behavior, I claim that the relative distance of MEPs' ideal locations from the positions of their two parties represents the relative influence of the two parties on their voting behavior. That is, the more the number of MEPs' ideal points of a national party is closer to the national party's position, the higher the national party cohesion result in.

Figure 3 presents the micro foundation of this claim using a simple one-dimensional spatial model. MEPs, in this model, are assumed to have Euclidean preferences. Without 
〈Figure 3〉 A Micro Foundation for National Party Cohesion*

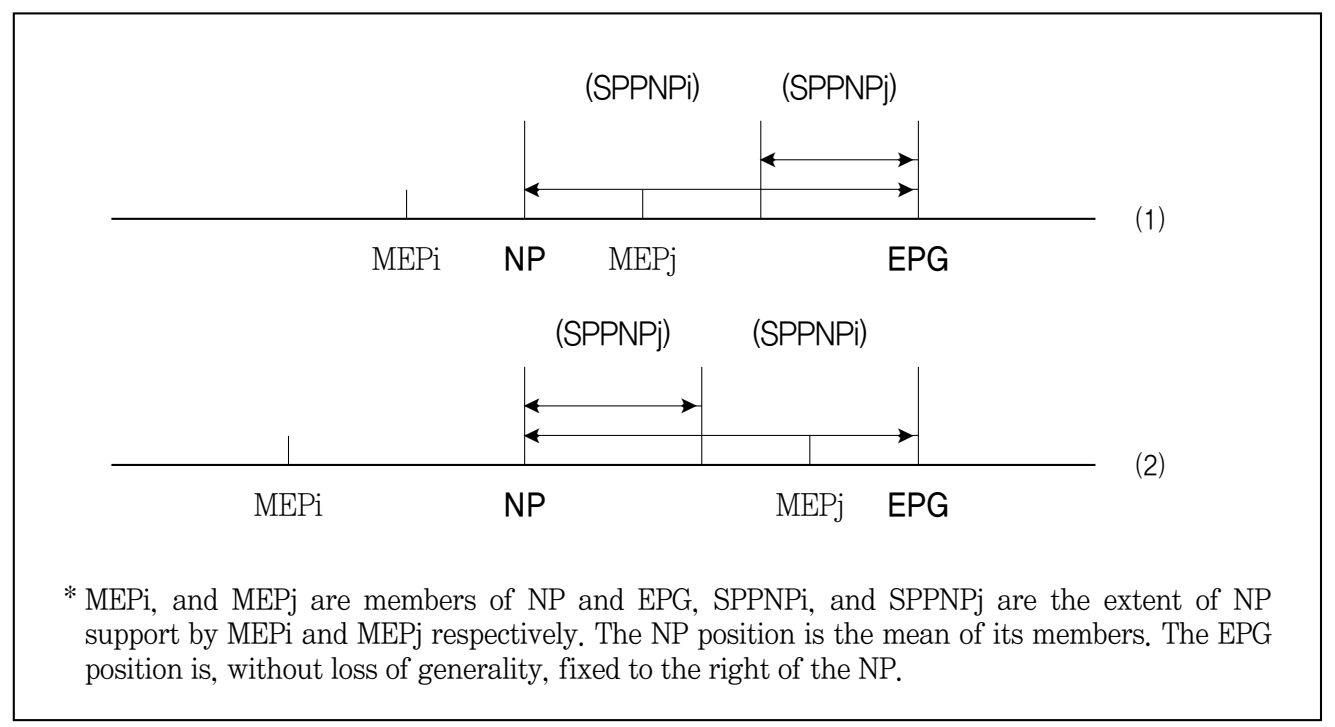

loss of generality, their preferences are represented by a distance function and thus are single-peaked with their respective ideal points. In other words, they prefer policies closer to their ideal points and are indifferent between policies with the same distance from their ideal points. The national party and the EPG to which MEPs have party membership in the two-level party system is denoted as NP and EPG respectively.

Using only two hypothetical MEPs, MEPi and MEPj, Figure 3 simply shows how the relative influence of their two parties can be represented by the relative distance of each MEP’s ideal point from the two parties. The only difference between two cases in Figure 3 is that two MEPs' relative distance from their two parties. In the case of the Figure 3 (1), since the ideal positions of MEPi and MEPj are closer to the NP's position than the EPG's, they support more frequently the NP's positions. Each MEP's utility gain from supporting for her NP's position than the EPG's would be

$$
\begin{aligned}
\mathrm{Ui}_{\mathrm{i}}(\mathrm{NPsupport})-\mathrm{Ui}_{\mathrm{i}} \text { (EPGsupport) } & =-|\mathrm{MEPi}-\mathrm{NP}|-(-|\mathrm{MEPi}-\mathrm{EPG}|) \\
& =\mathrm{EPG}-\mathrm{NP}=\mathrm{SPPNPi}>0 \\
\mathrm{Uj}_{\mathrm{j}}(\mathrm{NPsupport})-\mathrm{Uj}_{\mathrm{j}}(\mathrm{EPG} \text { support }) & =-|\mathrm{MEP}-\mathrm{NP}|-(-|\mathrm{MEP}-\mathrm{EPG}|) \\
& =-2 \mathrm{MEP}+\mathrm{EPG}+\mathrm{NP}=\mathrm{SPPNP}_{\mathrm{j}}>0
\end{aligned}
$$

From the utility calculation, we can say that both MEPs support more frequently their NP's position rather than the EPG's. By supporting their NP's position, both of them 
gain utility greater than zero.

In the case of the Figure 3(2), MEPj's ideal position is closer to the EPG's position than the NP's. Because of the change in MEPj's ideal location, we observe MEPi is located at a rather farther left position than in the case of the Figure 3(1). MEPi's utility gain from supporting for her NP's position in this second case does not change. Instead, MEPj now loses utility by supporting for her NP's position. From the calculation in equation (2), we now get $2 M E P j>E P G+N P$, which makes SPPNPj 〈O. Thus, unlike MEPi, MEPj will be less likely to support her NP's position. Therefore, while the mean distances between the NP and the EPG in both cases are same, the NP in the two cases should be viewed to have different levels of national party cohesion.

This simple spatial model thus helps us to develop a measure of national party cohesion inside the EP, which depends on the influence of the EPG on their members' voting behavior. The Empirical measure of national party cohesion inside the EP takes four steps.

First, relying on a Bayesian method of ideal point estimation, I estimate each MEP’s ideal point and the mean positions of each national party and the EPG from the First to the Fifth EP session. The estimated spatial information summarizes MEPs' real voting records by mapping their relative spatial locations in issue spaces. Second, I categorize each MEP into two types. If an MEP's relative distance from her two parties is closer to the NP, I coded the MEP as 1 . Otherwise, I coded her as 0. Thus, MEPs those who coded as 1 represent those who support their NP more frequently when there are conflicts between the NP and the EPG. Third, I aggregate the type of each MEP with respect to her national party membership. A national party with a greater number of their members coded as 1 than 0 represents the high cohesive national party. Finally, I standardize the aggregated measure with respect to the total number of MEPs assigned to each member state. The reason for this standardization is to control the variation in the number of MEPs among member states.

Formally, with $K=1,2, \cdots, k$ number of national parties in a member state and $i$ number of MEPs in each national party $k$ for $i=1,2, \cdots, n$, the level of each national party's cohesion,

'NPCOH,' can be written by following two steps.

$$
\begin{aligned}
\text { MEPCLOSE }_{k i} & =1 & & \text { if } \text { SPPNP }_{k i}>0 \\
& =0 & & \text { otherwise }
\end{aligned}
$$


and NPCLOSEki defines the two types of MEPs depending on their spatial locations between the mean positions of the two principals.

$$
\mathrm{NPCOH}_{k}=\frac{\sum_{i=1} \mathrm{MEPCLOSE}_{k i}}{\sum_{j=1} \mathrm{NUMNP}_{j}}
$$

where NPSPPk denotes the level of national party k's cohesion inside the EP, and NUMMEPj denotes the total number of MEPs of the national party $j$ where $j \in K$ and $\Sigma_{j}=1 \mathrm{NUMNP}_{j}$ denotes the total number of MEPs assigned to a member state.

Measured like this, the range of ' $\mathrm{NPCOH}$ ', is $0 \leq \mathrm{NPCOH}<1$. After the inevitable drop of observations, ${ }^{3)}$ the total number of observations considered here is 289 national parties consisting of 37 national parties in the First, 52 in the Second, 52 in the Third, 71 in the Fourth, and 77 in the Fifth EP.

Reminding the expectation from the theoretical model of MEPs' voting decision, the variations in the relative magnitude of MEPs' support for their national party majority would be positively related to the national party strength. Data in Table 2 shows the validity of this new measure.

〈Table 2〉 Party Strength and the Average National Party Cohesion*

\begin{tabular}{|c|c|}
\hline Institutional Strength of National Party & Average National Party Cohesion \\
\hline weak & 60.46 \\
\hline medium & 63.65 \\
\hline strong & 67.62 \\
\hline \multicolumn{2}{|c|}{$\begin{array}{l}\text { * For institutional strength of national party, a five-point scale, Lundall Index, of party } \\
\text { strength is used. The Weak category includes national parties measured by } 1 \text { and } 2 \\
\text { scales in Lundall Index. Medium category includes those measured by } 3 \text { and } 4 \text { scales. } \\
\text { The strong category includes those parties with } 5 \text { Lundall index. Average degree of NP } \\
\text { support is calculated by averaging the degree of NP support based on their members } \\
\text { ideal points among the national parties in each category. } 289 \text { national parties } \\
\text { considered in this article are categorized with respect to the party strength. }\end{array}$} \\
\hline
\end{tabular}

In Table 2, the party strength, created by Lundall(2004) with a five-point scale, is categorized into three groups. The relationship between the party strength and the average national party cohesion reveals that the weaker the national party strength, the

3) There are several reasons for this inevitable drop. For example, because of the identification of national party's mean position, parties with less than two members are excluded. On average, nine extremely small national parties in each EP session have been deleted from my data set. 
lower the national party cohesion. Even though the substantive variation is not so big, the positive relationship makes us confident of the measure as a fairly good refection of the relative magnitude of MEPs' support for their national party positions rather than their EPG's.

The new measure, thus, represents MEPs' strategic responsiveness to their national party supporters under the two-level party system. The biggest advantage of this new measure is that unlike the previous measure, the mean distance between the national party and the EPG, it can specify the direction of individual MEP's defection from their national party majority. Since the focus of national party cohesion lies on the relationship with the EPG, it is devised that the degree of national party cohesion is measured by the frequency of MEPs' defection from their national party under the conflicts between their two parties. Therefore, this new measure allows us to test the effect of national parties' responsiveness to their voters' electoral support consistent with their conflicting or cooperative relationship with the EPG.

\section{Data, Variable, Model and Hypotheses}

Data, to test the national parties' cohesion with respect to their responsiveness to voters' electoral choices, contains 289 national parties elected in previous five EP sessions from 1979 to 1999.

For the relevant election results, I rely on several resources: Corbett et al.(2005), Keesing's Archive of World Event, Europa Year Book and some on-line resources. ${ }^{4)}$ The gains and losses of seat shares are used to calculate electoral volatility of each national party. This use of seat shares may raise a question of the different proportionality among various electoral systems during the transfer of voter shares into seat shares (Taagepera and Schugart; 1989). However, while most member states have used similar proportional representation system in both the national and the EP elections, ${ }^{5}$ the seat share data was more consistent between various data sources than the vote shares they reported.

The measure of national party cohesion was developed from the estimation of MEPs'

4) Good on-line election resources are found in the Election Results at the Binghamton University, http://cdp.binghamton.edu/era/index.html, or German web site, http://www.parties-and-elections.de/index.html.

5) The exception is found in the UK. UK had used Single Member District Plurality System (SMDP) in both the national and the EP election by the 1994 EP election. From the 1999 EP election, the electoral system for the EP election changed into the Proportional Representation system(PR) even though SMDP was still used for national elections. 
ideal points in each EP session. Han(2007a) showed the advantage of using a Bayesian method in analyzing the EP roll call data and estimating MEPs' ideal points. The estimates applying the Bayesian method produces very similar outcomes to the standard method of ideal point estimation, NOMINATE. On average, the correlation between two estimates was more than $91 \%$.

I use Lundall Index(2004) to measure the institutionally determined national party strength. The index, developed from the consideration of candidate selection process, is a five-point ordinal scale measure. It is coded as 1 if the candidate selection process is the most dispersed into regional party members, and 5 if the selection process is the most centered on party leadership. There are two potential problems applying this index to measuring the effect of electoral institutions. ${ }^{6}$ First, it ignores other electoral institutions affecting the national party strength such as electoral system and district magnitude, and some potential interactions between them. ${ }^{7)}$ Second, it does not directly measure the party strength in the processes of EP elections, but is developed from the context of national elections. So, it would be at best a proxy measure of the party strength in EP elections. However, the index is the sole data currently available for the measure of party strength at the party level. Moreover, using this index as a proxy measure of party strength in EP elections, I assume that each national party might not run significantly different candidate selection processes between the national and the EP elections.

Finally, for the national parties' positions on the issues of European integration, I relied on the expert survey data collected by Marks and Steenbergen (1999), and for the post of EPGs' leadership inside the EP I use the information reported in the EP's internal documents.

With these various sources of data, I test the following linear model.

$$
\begin{aligned}
\text { NPCOH }_{k} & =\beta 0+\beta 1: 4 \text { ISSUE }_{k} \\
& +\beta 5 \text { NPSTRONG }_{k}+\beta 6 \text { ESIGNAL }_{k}+\beta 7 \text { INTER }_{k} \\
& +\beta 8 \text { EPGLEAD }_{k}+\beta 9 \text { NPSIZE }_{k}+\beta 10 \text { INTER }_{k} \\
& +\beta 11: 13 \text { MEPG }_{k}+\beta 14: 19 \mathrm{MNP}_{k}+\in_{k}
\end{aligned}
$$

6) There are another minor problem using this index. That is, the index does not include the data for parties in the Germany and the Finland. Gallagher(1988) resolves this problem by the fact that those states legally define the candidate selection processes. According to him, this legal defined processes could be coded as 2 denoting relatively weak party strength.

7) Hix(2004) provides good explanation on this problem. 
The statistical method used here for the analysis is the Ordinary Least Squares with Robust Errors. Although the data is both cross-sectional among member states and time series covering from the First and the Fifth EP, it is not appropriate to use an unbalanced panel approach because elections occur in different years for different member states(Carrubba 2001). However, the Chi-square test based on White's general heteroskedasticity test statistic shows that the errors are distributed with non-constant variance over observations with the value of White's test statistic, 286.39 under 26 degree of freedom and the zero $\mathrm{p}$-value of the $\chi^{2}$ test. Two common approaches to deal with this non-constant variance problem are the method of Generalized Least Squares (GLS) and that of OLS with Robust Errors. The results from the GLS regression were almost the same as those from the method used here.

The dependent variable denoted as ' $\mathrm{NPCOH'} \mathrm{in} \mathrm{equation} \mathrm{(5)} \mathrm{is} \mathrm{the} \mathrm{degree} \mathrm{of} \mathrm{national}$ parties' cohesion measured by the relative distance of party members' ideal points from the positions of their two parties. It represents MEPs' responsiveness of each national party to their party supporters through their voting decisions on the issues of conflicting between their two parties.

Two most important hypotheses in this analysis are derived in terms of the variables, denoted 'ESIGNAL,' and 'INTER1.' The term, 'ESIGNAL,' means the electoral volatility of each national party measure by the seat share difference between each EP election and the previous national election. The term, 'INTER1,' means the interaction between the electoral volatility 'ESIGNAL,' and the institutionally determined national party strength, 'NPSTRONG' measured by the Lundall index. From the theoretical model presented in previous section, the first main hypothesis is;

HP1: The aggregated magnitude of MEPs' supporting for their national party than their EPG is more likely to increase as electoral volatility between each EP election and the previous national elections increases.

The second main hypothesis considers the interaction effect between 'NPSTRONG' and 'ESIGNAL' Saying;

HP2: The positive effect of electoral volatility on national party cohesion is conditioned on institutionally determined national party strength.

Although it is specified by the theoretical model in the previous section, it is interesting to test how the influence of the EPG leadership on their members' voting behavior is 
conditioned on the EPG leaders' national party membership. That is, while it is not clear how the EPG leaders' national party membership may affect the national party cohesion or their member MEPs' voting decisions on the issue of conflicting between the national party and the EPG, it seems to be reasonable to assume that the role of the EPG leaders may differ depending on from which national party they are elected. In this regard, the third hypothesis is developed from the interaction between two variables; 'EPGLEAD,' which denotes a dummy variable measuring whether a national party has their members who serve as the EPG leaders such as the president of the EP and the chair of the committees inside the EP and 'NPSIZE,' which denotes the size of each national party measured by the seat shares in each EP session. The third hypothesis concerning the interaction between these two variables, 'INTER2,' is as follows;

HP3: The influence of the EPG leaders on national party cohesion developed from the relative magnitude of their member MEPs' support for their national party will be conditioned on from which national party the EPG leaders are elected.

While the variable, 'NPSIZE' is a proxy controlling for the effect of national politics claimed by the Second-Order model, other variables in equation (5), 'ISSUE, 'MEPG,' and 'MNP' are those controlling for national parties' positions on the issues of European integration, national parties' membership to the EPGs and their party identification. The term, 'ISSUE,' denotes a vector of four variables representing the national constituents' preferences and each national party's position on two issues, left/right ideological dimension and European integration dimension.

Using the expect survey data(Mark and Steenbergen; 1999), mean positions of national constituents and each national party's issue positions are constructed. The term, 'MEPG,' denotes a vector of three dummy variables considering the effect of national parties' membership to specific EPGs such as the Socialist group(SOC) and the group of the European people's party(EPP), and the group of the Greens(Greens). National parties' membership to the other EPGs such as the group of the Alliance of Liberals and Democrats for Europe(LIB) will be the baseline for comparison. The next term, 'MNP,' is a vector of six dummy variables representing the effects of six major national parties. German Christian Democratic party(CDU) and Socialist Democratic party(SPD), British Conservative party(CON) and British Labor party(LAB), French Conservative party (UDF) and Spanish Conservative party(PP) are included.

Finally, mean distance between the positions of national parties and their respective EPG is controlled. Previous research has usually used this variable to control the 
conflicts between the two parties. However, the level of conflicts itself does not determine which party MEPs would support. Modeled based on individual MEPs' strategic decisions, national parties' responsiveness would not be significantly affected by this simple mean distance between the two parties.

\section{Empirical Results}

Table 3 compares the empirical results from three models of European party representation. The first model, Institution Deterministic Model,' only considers the effect of institutionally determined national party strength. The second model, Electoral Model,' takes into account the simple effect of the electoral volatility. The third and main model, Strategic Response Model,' explains the interaction effect between

〈Table 3〉 Results from the OLS with Robust Error

\begin{tabular}{|c|c|c|c|}
\hline $\begin{array}{c}\text { Variables } \\
\text { (Dep: NPCOH) }\end{array}$ & $\begin{array}{c}\text { Inst.Deterministic } \\
\text { Mødel }\end{array}$ & Electoral Model & $\begin{array}{c}\text { Strategic } \\
\text { Response Model }\end{array}$ \\
\hline $\begin{array}{l}\text { Nation Mean Integ. } \\
\text { Party Mean Integ. } \\
\text { Nation Mean L/R } \\
\text { Party Mean L/R }\end{array}$ & $\begin{array}{c}-0.046(0.008) * * * \\
0.014(0.004)^{* * *} \\
0.011(0.006)^{*} \\
-0.010(0.029)\end{array}$ & $\begin{array}{r}-0.036(0.008)^{* * *} \\
0.012(0.003)^{* * *} \\
0.022(0.006)^{* * *} \\
-0.015(0.026)\end{array}$ & $\begin{array}{r}-0.035(0.008)^{* * * *} \\
0.012(0.003)^{* * *} \\
0.020(0.006)^{* * *} \\
-0.023(0.024)\end{array}$ \\
\hline $\begin{array}{l}\text { NP strength (Institutional) } \\
\text { Electoral Volatility (ESIGNAL) } \\
\text { ESIGNAL*NP strength }\end{array}$ & $0.010(0.006)^{*}$ & $\begin{array}{l}-0.003(0.005) \\
\quad 0.325(0.106)^{* * *}\end{array}$ & $\begin{array}{c}-0.000(0.005) \\
0.360(0.098) * * * \\
0.102(0.107)\end{array}$ \\
\hline $\begin{array}{l}\text { EPG leader } \\
\text { NP Size } \\
\text { NP Size* EPG leader }\end{array}$ & $0.059(0.020) * * *$ & $\begin{array}{l}0.012(0.011) \\
0.010(0.002)^{* * *}\end{array}$ & $\begin{array}{l}-0.013(0.010) \\
0.009(0.002)^{* * * *} \\
0.003(0.001)^{* * *}\end{array}$ \\
\hline Mean Distance & & $0.029(0.048)$ & $0.034(0.050)$ \\
\hline $\begin{array}{l}\text { EPP } \\
\text { SOC } \\
\text { Green } \\
\text { German CDU } \\
\text { German SPD } \\
\text { UK CON } \\
\text { UK LAB } \\
\text { France UDF } \\
\text { Spain PP } \\
\text { Constant }\end{array}$ & $\begin{array}{c}0.044(0.019)^{* *} \\
0.078(0.021)^{* * *} \\
-0.051(0.016)^{* * *} \\
0.108(0.032)^{* * *} \\
0.026(0.024) \\
0.150(0.046)^{* * *} \\
0.148(0.070)^{* *} \\
0.285(0.152)^{*} \\
0.112(0.018)^{* * *} \\
0.202(0.042)^{* * *}\end{array}$ & $\begin{array}{c}0.019(0.018) \\
0.018(0.020) \\
-0.037(0.013)^{* * *} \\
-0.229(0.085)^{* * *} \\
-0.208(0.060)^{* * *} \\
-0.158(0.060)^{* * *} \\
-0.176(0.054)^{* * *} \\
0.102(0.119) \\
-0.044(0.049) \\
0.141(0.040)^{* * *}\end{array}$ & $\begin{array}{c}0.021(0.017) \\
0.020(0.020) \\
-0.030(0.013)^{* *} \\
-0.240(0.087)^{* * *} \\
-0.195(0.056)^{* * *} \\
-0.200(0.074)^{* * *} \\
-0.146(0.054)^{* * *} \\
0.014(0.083) \\
-0.024(0.049) \\
0.246(0.039)^{* * *}\end{array}$ \\
\hline $\begin{array}{l}\text { Num. Obs. } \\
\text { R-squared } \\
\text { Root MSE }\end{array}$ & $\begin{array}{l}289 \\
0.403 \\
0.113\end{array}$ & $\begin{array}{l}289 \\
0.620 \\
0.091\end{array}$ & $\begin{array}{l}289 \\
0.653 \\
0.087\end{array}$ \\
\hline
\end{tabular}

*p $<0.10 ; *$ * $<<0.05 ; * * * p<0.01$ (two-tailed). Robust error in parentheses. 
electoral volatility and the institutional strength of each national party together with the interaction effect between the EPG leadership and the size of each national party.

The results in Table 3 overall confirm our expectation of model improvement and major hypotheses. According to the values of $\mathrm{R}$-Squared, the strategic response model improves the explanatory power compared to the other two simple models. While the electoral model explains more than $20 \%$ of data variation than the institution deterministic model, the strategic response model explains another $3 \%$ of the variation. The improvement between the models was statistically significant by two separate F-test.

Substantively, all three models present very similar results for variables related to the issue preferences. Interestingly, national party cohesion decreases as their national constituents prefer more European integration. This implies that MEPs from a member state strongly supporting for further European integration are more likely to behave as pan-European representatives and thus reduce the cohesiveness of their national party in European decision making. In addition, compared to the significant effect of European integration issue, ideological preferences among national constituents and party supporters do not show much significant influence. Thus, MEPs do not show different magnitude of supporting for their national party rather than the EPG based on their ideological locations.

Second, directions of coefficients of the variables concerning party membership have been changed between the models. Unlike the institution deterministic model, the other two models show that MEPs of the Green are more likely to follow the Green position than their national party positions. Moreover, the positive effects of MEPs' membership to the SOC and EPP in the first model vanish in the other two models. For the national party membership, MEPs of four major national parties are more likely to support for their respective EPG rather than their national parties. For instance, MEPs of the German CDU and the British Conservative party will vote more frequently for the positions of the EPP. The implication of these results would be that the major national parties would be main contributors to support the two major EPGs' positions rather than all the national party members of the EPGs.

Most interesting findings are derived from the six variables in the middle of Table 3. For the variables concerning electoral signals and party strength, the simple institution deterministic model shows a positive significant effect on the national party cohesion. However, this significant effect disappears after considering for the effect of voters' electoral signals and its interaction with party strength in the other two models. In particular, the strategic response model confirms the hypothesis 1 with the expected direction of coefficient of electoral volatility and its statistical significance. 
For the variables concerning EPG leadership and the size of national party, the simple institutional deterministic model reports even an implausible positive effect. That is, according to the result from this model, EPGs' leaders would enforce their members to support for their national party rather than the EPG. Meanwhile, the other two models correct this weird result. Although the effect of EPG leadership is insignificant, the result shows a substantively negative effect on national party cohesion. In addition, the interaction effect between EPG leadership and the size of national party reveals a significant positive effect on the national party cohesion.

However, it should be emphasized that using the results in Table 3, we are unable to draw more informative interpretation for the effects of interaction variables. Unlike the other variables, the marginal effects of the conjugate simple variables relevant to the interaction variables in Table 3 are valid only when either of the two simple variables consisting of each interaction variable is equal to zero. Recently, Brambor et al.(2006) redress the inferential problem with interaction variables by suggesting that the better inference from the interaction variable will be derived not from interpreting constitutive terms as if they are unconditional marginal effects, but from calculating substantively meaningful marginal effects and standard errors. Thus, the proper interpretation of the marginal effects of each simple variable could be calculated by taking the first derivative of the equation (5) with respect to each simple variable. ${ }^{8)}$ For example, the marginal effect of the institutional party strength, from the equation (5), is derived by;

$$
\frac{\partial \mathrm{NPCOH}}{\partial \mathrm{NPSTRONG}}=\beta 5+\beta 7 \mathrm{ESIGNAL}
$$

where $\beta 5$ was the coefficient of the variable, NPSTRONG, and $\beta 7$ was the coefficient of the variable, INTER1, which is constructed by the multiplication of two variables, NPSTRONG and ESIGNAL.

The standard errors of the marginal effect is again calculated by,

$$
\begin{aligned}
\frac{\partial \mathrm{NPCOH}}{\text { วNPSTRONG }} & =\operatorname{var}(\beta 5+\beta 7 \text { ESIGNAL }) \\
& \operatorname{var}(\beta 5)+\mathrm{ESIGNAL}^{2} * \operatorname{var}(\beta 7)+2 * \text { ESIGNAL } * \operatorname{var}(\beta 5, \beta 7)
\end{aligned}
$$

8) For the appropriate use of interaction variable and its interpretation, consult Friedrich (1982), Braumoeller(2004) and Brambor et al.(2005). 
Similarly, the marginal effects of electoral signals measured by the electoral volatility, of the EPG leadership and the party size are calculated.

〈Figure 4〉 Marginal Effects of Electoral Volatility and Party Strength on National Party Cohesion

(Figure 4.1) Marginal Effects of Electoral Volatility

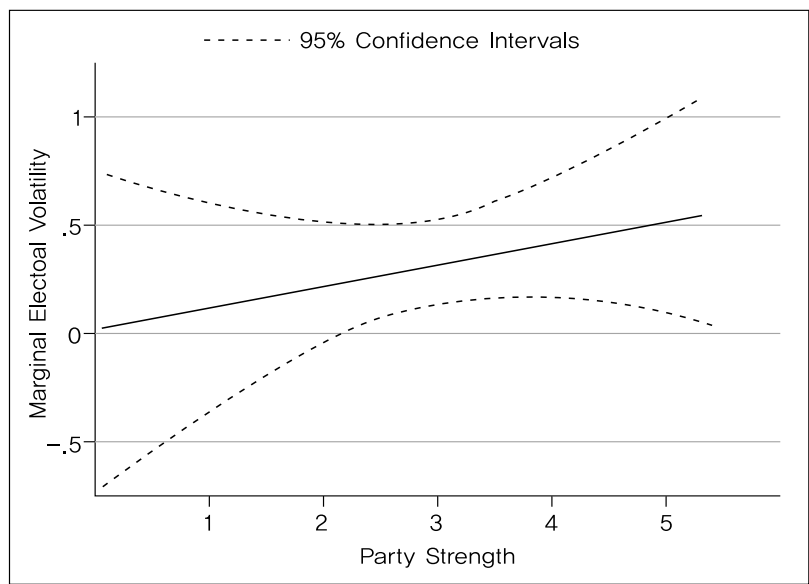

Note: When the party strength is 2.18 , the lower bound intersects the zero marginal effect.

(Figure 4.2) Marginal Effects of Party Strength

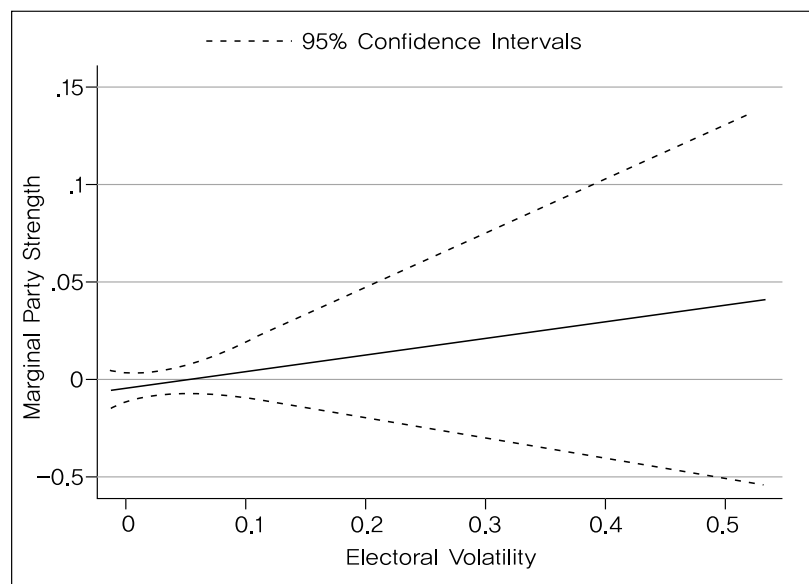

Note: In the ranges of electoral volatility less than 0.07 , the party strength has a substantively negative effect.

Figure 4 presents the marginal effects of electoral volatility and party strength constructing the first interaction variable. The marginal effects of each variable are drawn with solid line conditioned on the other relevant variable. The dotted lines represent the $95 \%$ confidence intervals of the marginal effects. The standard errors for 
the confidence interval are calculated using the similar calculation to the equation (7). As each graph reveals specific ranges of statistical significance conditioned on the other variable, the traditional statistical significance can be assessed with the $95 \%$ confidence intervals. In particular, regions that the confidence intervals do not include zero indicate statistically significant marginal effects.

Figure 4.2 at first shows that the marginal effects of party strength are not significant under all ranges of electoral volatility. However, the direction of effects confirms the hypothesis 1 from substantive perspective. When the electoral volatility is very low, i.e. lower than 0.07 , the national party strength has a negative effect on the magnitude of MEPs' supports for their national party under the conflicts between the national party and the EPG. Meanwhile, when the electoral volatility is greater than 0.07, the positive effect of party strength on national party cohesion is reinforced by electoral volatility.

More interestingly, Figure 4.1 shows how the significant effects of electoral volatility vary conditioned on party strength. If party strength is week, that is less than 2.18, then electoral volatility has no significant effect on national party cohesion. Meanwhile, when party strength is greater than 2.18 , the electoral volatility has significant positive effects on national party cohesion. This result again confirms the hypothesis 2 for the interaction effect between electoral volatility and party strength.

〈Figure 5〉 Marginal Effects of the EPG Leadership on National Party Cohesion

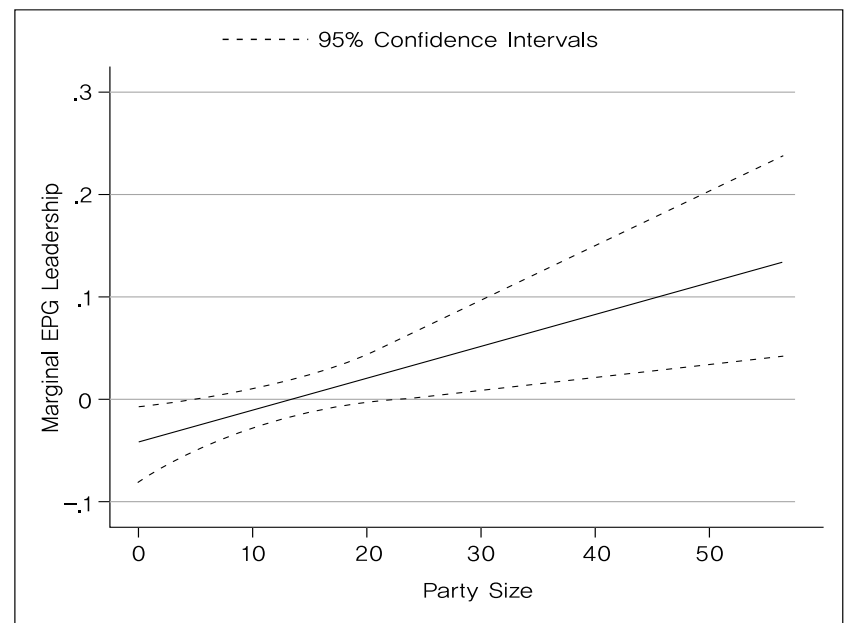

Note: In the range of party size less than 5.75, the Party leadership has a negative effect and in the range of party size greater than 23.03 , it has a positive effect. 
For the hypothesis 3, the marginal effects of EPG leadership is again illustrated graphically in Figure 5. We find two different directions to which EPG leadership are significant conditioned on the size of national party. That is, when the size of national party is small, that is, less than 5.75, the EPG leadership has a statistically significant negative effect on national party cohesion. In contrast, when the size of national party is fairly big, i.e. greater than 23.03, EPG leadership has a positive effect and it is also statistically significant. Only when an EPG leader was elected from medium sized national parties between 6 and 22, it does not have a significant effect on national party cohesion. This EPG leadership effect thus implies that while EPG leaders elected from a small national party push more strongly their members to support the EPG's position, those who elected from a large national party have less influence on their members' support for the EPG's position rather than their national party position.

\section{Conclusions}

This article considered the national parties' responsiveness to their party supporters in the two-level European party system. The institutional complexity in this system raised a challenging question of measuring national party cohesion because members of the EP make their voting decisions under the influence of both their national party and the EPG. Thus, whenever there are conflicts between the national party and the EPG, the influence of the EPG on their members' voting behavior makes it hard to implement the proposed policies in EP elections by the national party. As a result, linking voters' electoral choices into the 'enacted' public policies in this system has been a difficult question.

This article has tried to resolve the problem and show the current development of party responsiveness in the two-level party system. In so doing, MEPs' voting decisions were modeled to be determined by the stability of voters' party support between each EP election and the previous national elections, as well as the institutional strength of each national party. The frequency or magnitude of MEPs' support for their national party under the conflicts between the national party and the EPG is considered to measure national party cohesion. Empirical analysis confirmed major hypotheses concerning national party's responsiveness and its interaction with party strength. The analysis also found another interesting interaction effect concerning EPGs' leadership. It showed that EPGs' leadership depends on the size of national party from which leaders of each EPG are elected. Unexpectedly, EPG leaders of a large national party 
had a positive effect on the magnitude of MEPs' support for their national party position, not for the EPG' s position.

Overall, this article was the first scholarly effort to show national parties' policy responsiveness to European voters' electoral choices. From the results, it showed how parties perform their role in legislation in the two-level of party system, which would be empirical evidences for the development of a general theory about party representation in the multi-level of party system. 
Responding to Public : Policy Responsiveness by Political Parties in the European Parliament $\quad$ Han, JeongHun 175

\section{REFERENCES}

Attina, Fulvio. "The Voting Behavior of the European Parliament Members and the Problem of Europarties." European Journal of Political Research 18(3): 557579, 1990.

Brambor, Thomas, William Roberts Clarke, and Matt Golder. "Understanding Interaction Models: Improving Empirical Analyses.” Political Analysis 14(1):63-82, 2006.

Braumoeller, Bear F. "Hypothesis Testing and Multiplicative Interaction Terms." International Organization 58(4):807-820, 2004.

Butler, David and Donald E. Stokes. Political Change in Britain. New York: St. Martin Press, 1976.

Carrubba, Clifford J. "The Electoral Connection in European Union Politics." Journal of Politics 63(1):141-158, 2001.

Corbett, R., F. Jacobs and Shackleton, M. The European Parliament (5th ed). London: Catermill, 2005.

Crombez, Christophe. "The Co-decision Procedure in the European Union." Legislative Studies Quarterly 22: 97-119, 1997.

Dalton, Russell J., and Martin Wattenberg. Parties without Partisans: Political Change in Advanced Industrial Democracies. New York: Oxford University Press, 2001.

Ferrara, Federico, and J.Timo Weishaupt. "Get Your Act Together: Party Performance in European Parliament Elections." European Union Politics 5(3):282-306, 2004.

Friedrich, Robert J. "In Defense of Multiplicative Terms in Multiple Regression Equations." American Journal of Political Science 26(4):797-833, 1982.

Gabel, Matthew, and Simon Hix. "Defining the EU Political Space: An Empirical Study of the European Elections Manifestos, 1979-1999." Comparative Political Studies 35(8):934-964, 2002.

Gallagher, Michael. “Conclusion.” Michael Gallagher and Michael Marsh, eds. Candidate Selection in Comparative Perspective: The Secret Garden of Politics. pp.23688, London: Sage Publication, 1988.

Han, JeongHun. "Analyzing Roll Calls of the European Parliament: A Bayesian Application.” European Union Politics. 8(4):481-509, 2007 a.

Han, JeongHun. "How is the Relative Legislating Power Distributed Among European Institutions? A Model of Co-decision II Procedure." Working Paper. URL: http://troi.cc.rochester.edu/ jhan (consulted May 2006), $2007 \mathrm{~b}$. 
Hix, Simon. "Electoral Institutions and Legislative Behavior: Explaining Voting Defection in the European Parliament.” World Politics 56(2):194-223, 2004.

Hix, Simon, Abdul Noury and Gerard Roland. "Dimensions of Politics in the European Parliament." American Journal of Political Science 50(2):494-511, 2006.

Hix, Simon, Abdul Noury and Gerard Roland. Democratic Pollitics in the European Parliament. Cambridge: Cambridge University Press, 2007.

Katz, Richard S. Party Government: European and American Experiences. New York: de Gruyter, 1987.

Kousser, T.B. "Retrospective Voting and Strategic Behavior in European Parliament Elections.” Electoral Studies 22(1):1-21, 2003.

Kreppel, Amie. "Rules, Ideology and Coalition Formation in the European Parliament." European Union Politics 1(3):340-362, 2000.

Kreppel, Amie. The European Parliament and Supranational Party System: A Study in Institutional Development. Cambridge University Press, 2002.

Levitt, Steven D. "How Do Senators Vote? Disentangling the Role of Voter Preferences, Party Affiliation, and Senator Ideology." American Economic Review 86(4): 425-441, 1996.

Lundell, Krister. "Determinants of Candidate Selection: The Degree of Centralization in Comparative Perspective." Party Politics 10(1):25-47, 2004.

Marks, Gary and Marco Steenbergen. "Data Set Page." URL (consulted May 2006): http://www.unc.edu/ gwmarks/data.htm. 1999.

Oppenhuis, Erik, Cees van der Eijk and Mark Franklin. "The party Context: Outcomes." Cees van der Eijk and Mark Franklin, eds. Choosing Europe: The European Electorate and National politics in the Face of Union. Ann Arbor: The University of Michigan press, 1996.

Powell, G. Bingham, Jr. Elections as Instruments of Democracy: Majoritarian and Proportional Visions. New Haven: Yale University Press, 2000.

Ranney, Austin. The Doctrine of Responsible Party Government. Urbana: University of Illinois Press, 1962.

Raunio, Tapio. Party Group Behavior in the European Parliament: An Analysis of Transnational Political Groups in the 1989-94 Parliament. Tampere: University of Tampere Press, 1996.

Reif, K., and Schmitt, H. "Nine Second-Order National Elections: A Conceptual Framework for the Analysis of European Election Results." European Journal of Political Research 8(1):3-45, 1980. 
Reif, K. "National Electoral Cycles and European Elections." Electoral Studies 3 (3):244-55, 1984.

Reif, K. "Ten Second-Order Elections." Karlheinz Reif, ed. Ten European Elections. pp:1-36. Aldershot: Gower, 1985.

Sartori, Giovanni. "Representational Systems." International Encyclopedia of the Social Science 13:470-75, 1968.

Schmitt, Hermann, and Jacques Thomassen. Political Representation and Legitimacy in the European Union. Oxford University Press, 1999.

Schmitt, Hermann, and Jacques Thomassen. "Dynamic Representation: The Case of European Integration.” European Union Politics 1(3):318-339, 2000.

Taagepera, Rein, and Mattew Soberg Shugart. Seats and Votes: The Effects and Determinants of Electoral Systems. New Haven: Yale University Press, 1989.

van der Eijk, Cees, Mark Franklin, and Michael Marsh. "What Voters Teach Us About Europe-Wide Elections: What Europe-Wide Elections Teach Us About Voters." Electoral Studies 15(2): 149-166, 1996. 